UDC 621.386:616-073.7 (045),

DOI: $10.18372 / 1990-5548.52 .11882$

\author{
${ }^{1}$ N. I. Aralova, \\ ${ }^{2}$ O. M. Klyuchko, \\ ${ }^{3}$ V. I. Mashkin, \\ ${ }^{4}$ I. V. Mashkina
}

\title{
ALGORITHMIC AND PROGRAM SUPPORT FOR OPTIMIZATION OF INTERVAL HYPOXIC TRAINING MODES SELECTION OF PILOTS
}

\author{
${ }^{1,3}$ Institute of Cybernetics of V. M. Glushkov National Academy of Sciences of Ukraine, Kyiv, Ukraine \\ ${ }^{2}$ Educational \& Research Institute of Air Navigation, National Aviation University, Kyiv, Ukraine \\ ${ }^{4}$ Borys Grinchenko Kyiv University, Kyiv, Ukraine \\ E-mails: ${ }^{1}$ aralova@ukr.net, ${ }^{2}$ iesy@nau.edu.ua, ${ }^{3}$ mashkin_v@ukr.net, ${ }^{4}$ mashkina.iv@gmail.com
}

\begin{abstract}
A complex of mathematical, algorithmic and software tools for optimization of the choice of interval hypoxic modes training is presented in this article for flying personnel. The work is aimed at increasing of adaptation, efficiency and resistance of flight crew members. The basis of the mathematical model is the mass transfer and mass exchange of oxygen, carbon dioxide and nitrogen in human organism. There is suggested the solution of problem of tissue blood circulation predictions as result of conflict situation that occurs in human organism during internal and external disturbances between executive organ tissues and self-regulation tissues. The distribution of systemic blood circulation by tissues is realized in accordance with the hypoxic or hypercapnic stimulus, therefore the problem is formulated as a quadratic programming problem. An iterative procedure for studying and estimation of the gas state of respiratory system is suggested using an interval hypoxic training, which can contribute to the professional skill improvement of flight crews, their physical and psychological efficiency and readiness to perform complex educational and combat tasks in limited space and conditions of unfavorable external environment.
\end{abstract}

Index Terms - Interval hypoxic training; mathematical model of the respiratory system; secondary tissue hypoxia; self-regulation of the respiratory system.

\section{INTRODUCTION}

The work of flight crew members is one of the most difficult forms of human activity because it is carried out in a three-dimensional space under the constant influence of extreme physical and mental flight factors, under the conditions of constant readiness to change the flight regime [1]. Also, the unfavorable factors are the forcedness of the working pose, the limited space in the cabin, the rapid changes of external and internal circumstances of the flight. The high compulsory activity regimes, their time limits coupled with the fast information flow cause highly intensive mode of pilot work. These reasons cause significant increase in the level of functioning of the physiological systems of pilot organism in the pre-starter period and during the flight [2], [3].

\section{Problem Statement}

In paper [1] it was profoundly substantiated that the special physical training successfully solves problems for certain periods of increasing of the professional skills of flight crews - re-training for a new type of aircraft (helicopter), trainings of flights at small and extremely small heights, training of flights for complex types of combat application (for air combat), restoration of flying skills after a long break in flight activity.

All this emphasizes the actuality of the search and development of practical recommendations for improving the personnel's ability to perform assigned tasks.

Although the flight hours of the crew were and also remains the basis of its reliability, the general and special physical training of the pilots has a beneficial effect on the formation and development of professionally important qualities of the flight personnel of all types of aviation. The purpose of the physical training of pilots is to form their physical and psychological readiness to study the complex aircraft equipment, its effective use, high psychophysiological reliability of the organism in conditions of training-combat and combat work, increase of the reliability and capabilities of the flight crew bodies for rapid adaptation to the work in conditions of increased situational stress and extreme changes of external environment [1], [4].

The purpose of the work is to introduce a complex of mathematical and algorithmic support for the choice of optimal regimes of interval hypoxic training for flight personnel. 


\section{PROBLEM SOLUTION}

The reliability model for the functional state of operators of continuously interaction system, which also includes members of flight crews was suggested previously on the basis of reliability methods theory. A model was proposed in the form of a chain with a "weak link", and it is substantiated that persons "weak link" is a breathing system and a system of psychophysiological functions (see [4], [5]).

\section{A. Interval hypoxic training}

One of methods for the improving of the reliability and resistance of respiratory system is the interval hypoxic training (IHT) [6], which like other types of hypoxic effects, is based on the body's response to reducing of partial pressure $\mathrm{pO}_{2}$ in inhaled air. This reaction depends on gender, age, degree of adaptability of organism to low $\mathrm{pO}_{2}$, genetically determined individual characteristics, and the strength and duration of hypoxic stimuli - the gradient of $\mathrm{pO}_{2}$ reduction and duration of inhalation of air with low $\mathrm{pO}_{2}$ [7].

The concept of secondary tissue hypoxia was suggested by A. Z. Kolchinskaya [8] According to it the tissue hypoxia is not an obvious characteristic of hypoxic state, it has allowed to some extent to differentiate the destructive and constructive (creative, training) effect of hypoxic influence.

According to [7], the compensation of hypoxia is realized by mechanisms, aimed on:

- reduction of arterial hypoxemia and maintenance of velocity of delivery in the lungs and alveoli at a level close to the normoxic values by increasing of the breath minute volume;

- providing of speed growth for oxygen mass transportation from the blood to the tissues through the increasing of blood oxygen capacity by enhancing of the hemoglobin content and its ability to couple oxygen in lungs, to give it to tissues and to increase the volume velocity of blood circulation;

- providing of cells by the required amount of oxygen through the enhancing of the micro circulation of blood in tissues, reducing of oxygen diffusion distance from micro vessels blood into the cells and increasing of the oxygen stores as a result of increased myoglobin in tissues;

- increasing of cell abilities for oxygen utilization at low blood and plasma tension by increasing of mitochondria number, their respiratory ensembles, activity of respiratory enzymes and antioxidant system.

Peculiarities of mechanisms of IHT influence on human organism are that it is conducted at the background of planned training, including sports training.

Damaging effect of hypoxia consequences may occur also a positive effect on organism [7]. Under the normal conditions, the smooth muscles in vessels and the muscular elements of small blood vessels support the tone of vessels that decreases of their cross-section and increases of resistance to blood circulation. In resting muscles the most of micro vessels are not included into the general blood circulation. Around these vessels $\mathrm{pO}_{2}$ is lower than critical levels. With the decrease of $\mathrm{pO}_{2}$ in the inhaled air, the organism redistributes oxygen in such a way that increased blood circulation is obtained by such tissues as brain, heart, liver; in other tissues blood circulation does not increase. The arteries that supply the blood to the brain, heart, and liver are expanding. The arteries in muscles, arteries of the skin become scarred, their lumens and the area of cross section are reduced, but the blood flow resistance rises.

With hypobaric hypoxia on low arterial blood pressure $\mathrm{pO}_{2}$, aorta and sonar artery chemo receptors primarily react, resulting an increased external respiration. Irritation of these receptors is also responsible for the increasing of blood circulation volume velocity, its redistribution in organs, blood release from the blood depot - consequently, the amount of hemoglobin and red blood cells increases in circulating blood. Compensatory reactions at hypobaric hypoxia are also the most noticeable in such tissues as brain, heart and hematopoietic organs.

As already was mentioned earlier, not only the strength of hypoxic action, but also its extent determine the organism response to hypoxia. Interval hypoxic training creates the most optimal conditions for the demonstration of compensatory reactions effectiveness [6]. During the short time of $\mathrm{pO}_{2}$ influence on organism its damaging effect on the tissue structural elements cannot be fully realized yet. During inhaling $f$ the air with normocentric $\mathrm{pO}_{2}$ (in interval mode) the activity of compensatory mechanisms remains high; the cells of brain, heart and respiratory muscles continue to obtain more blood, energy substrates, oxygen and some other substances. In addition, due to the accelerated blood circulation, metabolic products are removed more quickly. All this forms the best conditions for biosynthesis.

Tissue hypoxia and biochemical, structural changes it occurs can limit work ability, lead to fatigue and to significant worsening of organism condition state. However, if hypoxia action is shortterm and repeated, if the hypoxic influence is shortterm and repeated - it means that interval hypoxic training is performed. In this case reversible effects of tissue hypoxia may cause a constructive effect.

The advantage of IHT in comparison with other types of hypoxic effects is so, that it does not change 
the normal conditions of human life, That is why the members of flight crews may undergo a course of interval hypoxic training without the interrupting of theoretical and practical combat training, including flight. It is known that in the fighter and assault aviation for the normal professional functioning the pilot has to have 5-6 flight hours per week [1]. This not only maintains his skills in piloting technology, but also trains his ability to work.

In conducting of interval hypoxic training the priority is given to the competent selection of training force of influence taking into account the individual capabilities of organism. In this case, the most positive effect is achieved only when, from one side, the degree of hypoxia is sufficient to cause visible reciprocal reaction from the systems responsible for transport and utilization of oxygen, and from other side, the development of deep tissue hypoxia is excluded.

\section{B. Mathematic model of respiratory system}

For the solution of this task, the application of imitation modeling to IHT process on mathematical model of respiratory gases mass transfer in human organism is proposed.

Previously the mathematical model for mass transfer of respiratory gases, nitrogen and water vapor in the whole organism was presented taking into account the basic structural and functional features of respiratory and blood circulation systems [9]. The model is constructed using the idea of compartmental modeling. It means that the process of mass transfer of respiratory gases is described using functionally interconnected but relatively autonomous compartments (conditionally isolated tissues of the brain, heart, liver and gastrointestinal tract, kidneys, skeletal muscles, skin, fat and bone tissues). This is a system of ordinary nonlinear differential equations with distributed or concentrated parameters constructed on the basis of the principles of material balance and flow indistinguishability, using known empirical dependencies between variables.

During the consideration of the task of predicting the behavior of the main gas parameters in respiratory system, which include the values of partial pressure of respiratory gases in lung structures, respiratory gases tensions in different portions of blood and tissues of organism, blood acidity, degree of hemoglobin and myoglobin saturation by oxygen, etc. appeared some questions related with formation of control parameters for respiratory system functioning. It is known that on gas tensions in respiratory system structures some values occur significant influence. There are values of ventilation $\dot{V}$ (or com- ponents that determine it - values of respiratory lung volume, duration of inhalation, exhalation and respiratory pause), volume velocity of circulatory system $Q$ and blood circulation in organ capillaries $Q_{t_{i}}$, $i \in I=\{1, \ldots, m\}$. That is why the values $\dot{V}, Q, Q_{t_{i}}$, $i \in I$ may be considered as control parameters for models of gas dynamics in respiratory human system.

In publications [10], [11] the mathematical models for the gas state in respiratory system are proposed; they are based on known physiological principles for determined field of regulation: hypoxic, hypercapnic and hyperacoustic. The task of studied dynamical system control is considered as the task of optimal control [12]. In its terms it is the task to transfer the dynamic system from known initial state to certain stable state under the new life conditions taking into account the interval imitations for control parameters [12] $\quad \dot{V}, Q, Q_{t_{i}}, \quad i \in I, \quad$ condition $\sum_{i \in I} Q_{i} \leq Q$ and minimization of functional

$$
\begin{array}{r}
J=\int_{\tau_{0}}^{\tau_{0}+T}\left[\rho_{1} \sum_{i \in I} \lambda_{i}\left(G_{t_{i}} \mathrm{O}_{2}-q_{t_{i}} \mathrm{O}_{2}\right)^{2}+\rho_{2} \sum_{i \in I} \lambda_{i}\left(G_{t_{i}} C O_{2}\right.\right. \\
\left.\left.+q_{t_{i}} C O_{2}\right)^{2}+\rho_{3} \sum_{i \in I} \lambda_{i}\left(G_{t_{i}} \mathrm{~N}_{2}\right)^{2}\right] d t,
\end{array}
$$

where $\tau_{0}$ is the time moment of influence beginning of external or internal disturbing factors; $\rho_{1}, \rho_{2}$ and $\rho_{3}$ are coefficients of organism sensitivity to hypoxia, hypercapnia and nitrogen saturation; $\lambda_{i}, i \in I$ are coefficients that characterize the morphofunctional features of organism tissues; $q_{t_{i}} \mathrm{O}_{2}$ and $q_{t_{i}} \mathrm{CO}_{2}$ is the velocity of oxygen utilization and carbon emission by $i$ th tissue region. $G_{t_{i}} \mathrm{O}_{2}, G_{t_{i}} \mathrm{CO}_{2}$ and $G_{t_{i}} \mathrm{~N}_{2}$ are flows, respectively oxygen, carbon dioxide and nitrogen through the tissue-capillary barrier into $i$ th tissue, which varies in time in accordance with the changing of life conditions; $T$ is given the interval of integration.

In publication [13] was proposed to reduce the dimension of control vector, assuming that, in addition to ventilation values $\dot{V}$ and systemic circulation $Q$, which are measured experimentally, tissue blood circulations $Q_{t_{i}}$ also known. By simulating of gas processes at small time intervals it is possible to determine the stationary gas state that corresponds to the moment of the experiment. The analysis of stationary gas states, obtained for different moments of time, allows us to evaluate the parameters of adaptation process.

Due to the fact that it is practically impossible to measure the tissue circulation [13], enough simple 
algorithm for distributing of systemic blood flow through fabric capillaries is proposed.

Let's study the problem of prognostication of tissue circulation under the conditions that the distribution of systemic circulation is carried out by tissue capillaries in accordance with hypoxic or hypercapnic principles. Then the problem may be formulated as a quadratic programming problem [14]: for the minimization of the function

$$
\begin{aligned}
f\left(Q_{1}, \ldots, Q_{m}\right)=\sum_{i \in I} \sigma_{i}\left(Q_{i}, \ldots, Q_{i}^{\prime}\right)^{2} & \\
& +\sum_{i \in I} \mu_{i}\left(Q_{i}, \ldots, Q_{i}^{\prime}\right)^{2} .
\end{aligned}
$$

under the limitations

$$
\begin{gathered}
\sum_{i \in I} Q_{i}=Q, \\
Q_{i} \geq Q_{i}^{\text {min }}, \quad i \in I,
\end{gathered}
$$

where $\sigma_{i}, \mu_{i}$ are coefficients of sensitivity of $i$ th tissue to the development of hypoxia and hypercapnia in it (it is assumed that $\left.\sigma_{i}+\mu_{i}=1, i \in I\right), Q_{i}^{\prime}, Q_{i}^{\prime \prime}, i \in I$ are regional blood flow determined in the result of distribution of blood circulation according to hypoxic and hypercapnic principles separately.

In publication [15] the method of stated task solution is proposed by means of a stepwise solving of quadratic programming problem without taking into account the restrictions of the form (3) of smaller dimension. Then the solution of the problem (1) (3) in general form may be represented as

$$
Q_{i}=\left\{\begin{array}{l}
Q_{i}^{\min }, i \in I^{q}=\left\{i_{1}, i_{2}, \ldots, i_{q}\right\} \in I, \\
\sigma_{i} Q_{i}^{\prime}+\mu_{i} Q^{\prime \prime}+\left(Q-\sum_{i \in I^{q}} Q_{i}^{\min }\right. \\
\left.\quad-\sum_{i \in I I^{q}}\left(\sigma_{i} Q_{i}^{\prime}+\sigma_{i} Q_{i}^{\prime \prime}\right)\right) /(m-q), \\
i \in I \backslash I^{q},
\end{array}\right.
$$

where $I^{q}$ is the number of indices of those tissue blood circuits $Q_{i}$ for which, in accordance with the proposed algorithm, the minimal possible blood flows are determined $Q_{i}^{\min }$.

Let's note that values $Q_{i}^{\prime}, Q_{i}^{\prime \prime}$ used in task (1) (3) can be obtained as a solution of the analogous tasks of quadratic programming: to minimize the function

$$
\begin{array}{r}
f\left(Q_{1}^{\prime}, \ldots, Q_{m}^{\prime}\right)=\sum_{i \in I} \sigma_{i}\left(Q_{i}^{\prime}-Q_{i}^{*}\right)^{2}, \\
\text { or } \quad f\left(Q_{1}^{\prime \prime}, \ldots, Q_{m}^{\prime \prime}\right)=\sum_{i \in I} \sigma_{i}\left(Q_{i}^{\prime \prime}-Q_{i}^{* *}\right)^{2},
\end{array}
$$

with restrictions of the form (2), (3) where the quantities $Q_{i}^{*}, Q_{i}^{* *}$ in tasks (2), (3), (5) and (2), (3), (6) are known, since they can be predefined on the basis of algebraic analogue of Fick's rule from the rates of oxygen utilization, carbon production and the values of the arterial and venous difference in concentrations of these gases that can be given or measured experimentally.

For IHT simulation a series of data are used for fed of programming complex input. This data can be divided into separate blocks that characterize the functional peculiarities of subsystems, which are modeled:

- data used by programming complex during the organization of computing experiment; they fulfill the control of this programming complex;

- data describing the morphological features of the human organism (weight of the individual, weight of different organs, the distribution of blood flow in different parts of circulatory system, etc.);

- control parameters, which are formed by the executive bodies of process regulation of gases mass transfer (pulmonary and alveolar ventilation and their components, systemic circulation, hemoglobin, acidity and the number of blood buffer bases, the number of erythrocytes, myoglobin, etc.);

- parameters of internal disturbing influences (velocity of oxygen consumption by organizm and individual organs, etc.);

- internal perturbing influences that characterize pathology and changes in respiratory system (partial occlusion of blood vessels, myocardium hypertrophy, increased pulmonary bypass, etc.);

- external perturbing influences characterizing the environment in which the object of research is located (environmental temperature, gas composition of the inhaled mixture, amount of water vapor, etc.);

- parameters that are physiological, biochemical and biophysical constants (coefficients of gases solubility, diffusion coefficients, etc.).

\section{Program complex for study of interval hypoxic training imitation}

An algorithm for studying and evaluating the gas state of the human respiratory system using interval hypoxic training is presented in Fig. 1.

The iterative procedure of the program complex is as follows:

- the input is made through the input block by setting the initial data (anthropometric data, data on the external environment, initial partial pressure and gas tension in the pulmonary structures, blood and tissues, parameters of the modes of external respiration, parameters of circulatory regimes, parameters 
characterizing the quantitative parameters of blood Amount of hemoglobin, acidity of blood, amount of balance of buffer bases of blood, myoglobin content; data defining the mode of work of the simulation model; biochemical and biophysical constants;

- then proceed to the block simulating the interval hypoxic training, it specifies the time intervals and the composition of the gas mixture to simulate the process of breathing;

- in accordance with the algorithm of interval hypoxic training formed data about the external environment;
- indicators of the gas state of the organism are predicted when simulating the transport model and the mass transfer of respiratory gases in the body in one respiratory cycle, provided that the control parameters remain constant;

- the implementation of mechanisms of selfregulation and adaptation of the organism to the conditions of the environment, in particular the distribution of systemic circulation on the organ [13];

- an analysis and evaluation of the received gas state of the respiratory system is carried out and a decision is taken on the end of the experiment or another one simulation cycle.

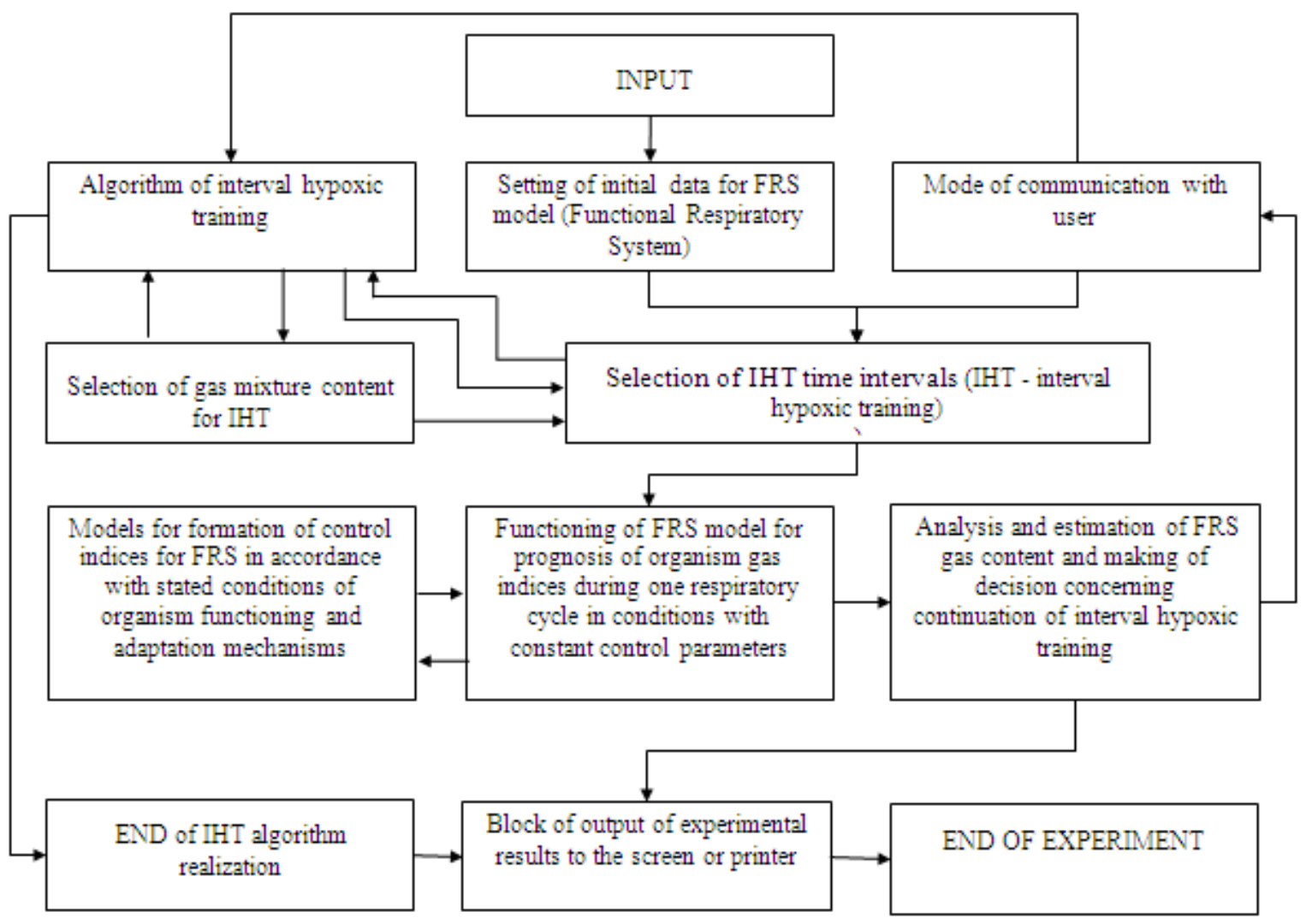

Fig. 1. Algorithm of the program complex for simulating the process of interval hypoxic training of pilots

Then to select the optimal mode of interval hypoxic training you can offer a program complex (Fig. 2) similar to ones at [16], [17].

\section{Programming complex for studying of interval} hypoxic training imitation

An algorithm for studying and evaluating of gas state in human respiratory system using interval hypoxic training was developed at the first stage of the work.

The iterative procedure of the program complex functioning is as follows:

- the input is made through the input block by setting the initial data (anthropometric data, data of the external environment, initial partial pressures and gas tensions in the pulmonary structures, blood and tissues, parameters of external respiration modes, parameters of circulatory regimes, parameters characterizing the quantitative parameters of blood amount of hemoglobin, acidity of blood, amount of balance of blood buffer bases, myoglobin content; data defining the mode of imitation model functioning; biochemical and biophysical constants;

- then a going to the block simulating the interval hypoxic training, it specifies the time intervals and the composition of the gas mixture for the simulation of breath process;

- in accordance with the algorithm of interval hypoxic training the data about the external environment are formed;

- indicators of the gas state of organism are predicted using organism respiratory gases transport 
model and mass transfer model during one respiratory cycle at conditions that the control parameters remain constant;

- realization of mechanisms of self-regulation and adaptation of organism to environment conditions, in particular - the distribution of systemic circulation on the organ circulation [13];
- analysis and evaluation of the received gas state of the respiratory system is carried out. Also the decision about the ending of the experiment or to continue it one more simulation cycle is taken.

Then to select the optimal mode of interval hypoxic training you can offer to use our developed program complex, similar to one described in [16], [7].

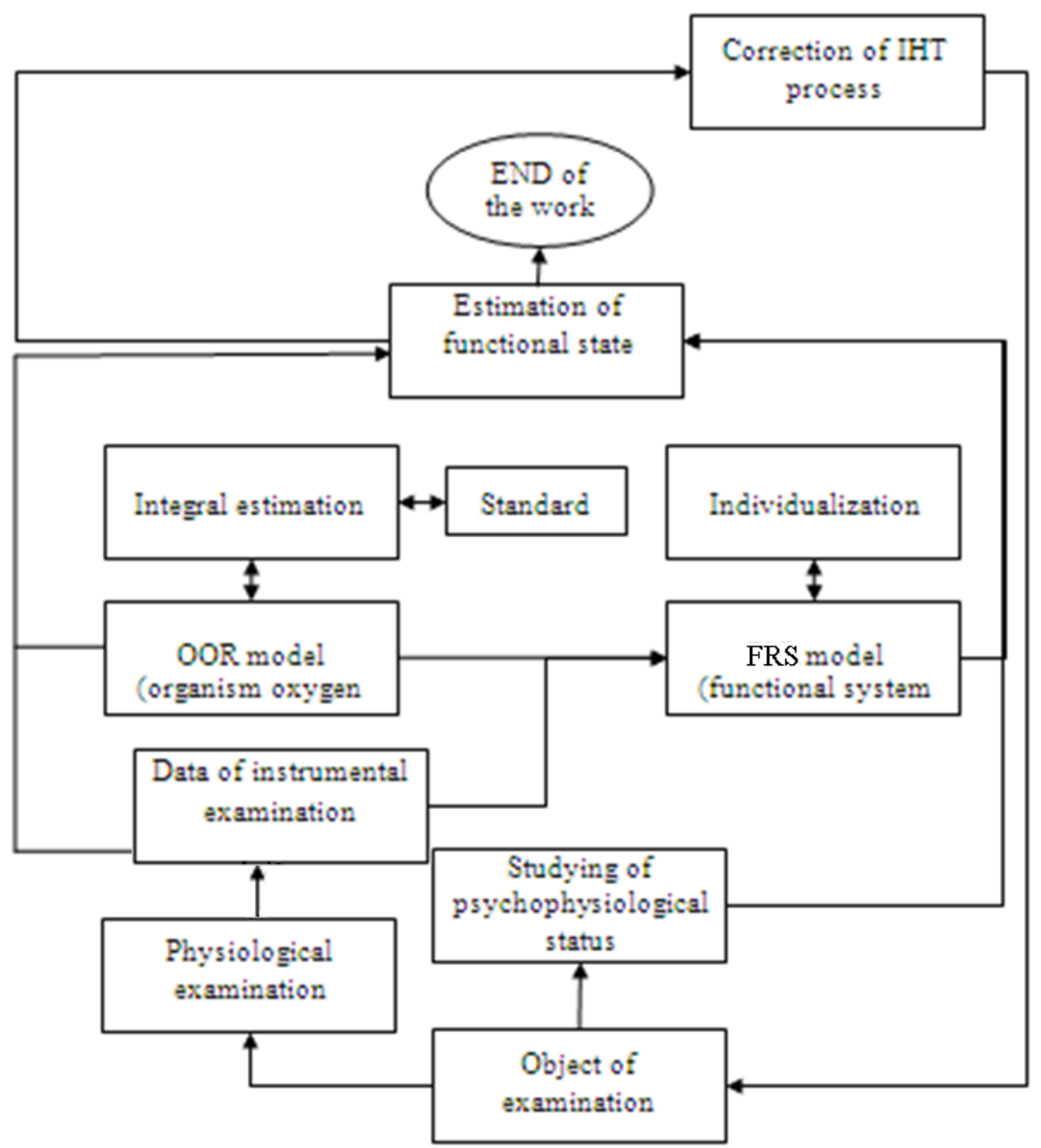

Fig. 2. Algorithm of software complex functioning to optimize the choice of modes of interval hypoxic training for flying personnel

E. Software for the optimization of choice for IHT modes

The iterative procedure for applying the proposed software then will look like following.

1. An instrumental study of operator is conducted and data model is developed basing on the results of laboratory studies. During the study ventilation, gas composition of alveolar and exhaled air, respiration frequency, cardiac contractions frequency, blood pressure, hemoglobin amount, blood acidity, and others are determined.

2 . Results of these studies are input into the model of organism oxygen regimes (OOR), which allows obtain a number of data concerning pilot functional state, part of these data may be used as input ones for respiratory gases transport model.
3. On the basis of the static model, an integrated estimation of cardiopulmonary system of examined individual is carried out.

4. The data obtained during the physiological study and calculated as results of static model operation have to be used as input data for respiratory gas transport model. This model is individualized by selecting of sensitivity coefficients for hypoparathy and hypercapnia; using it the simulation of an interval hypoxic training is possible. Using this model also the gas composition for hybrid mixture as well as time intervals during which gipobaric and normobaric mixtures are inhaled can be selected.

5. Obtained data are analyzed and the decision of IHT continuation is made (continuation with the 
same parameters or with changed ones - time interval or composition of the gas mixture).

6. A decision on the most optimal variant of interval hypoxic training for particular individual is made.

\section{CONCLUSION}

Proposed programmed complex with software package for optimizing of selection process for IHT regimes may be useful in carrying out of interval hypoxic trainings of flight crew members in order to upgrade personnel functional status for the fulfilling of their tasks.

\section{REFERENCES}

[1] F. I. Popov, A. I. Maracushin, and N. N. Breslavetz, "Physical preparation of fly crews - component of flies safety," Physical upbringing of students, no. 3, pp. 76-79, 2011 (in Russian).

[2] Aviation medicine. Edited by N. M. Rudny, P. V. Vasiliev, and S. A. Gozulova. Moskow, Medicine, 1986, 580 p. (in Russian).

[3] P. N. Makarov, Physical preparation of pilots for military aviation. Moskow, Yu. A. Gagarin BBA, 1979, 208 p. (in Russian).

[4]. N. I. Aralova. "Complex of information support for investigation of operators reliability work with continuous interactive systems in conditions of increased tension of situation," Science and innovation, vol. 12, no. 2, pp. 15-25, 2016. (in Ukrainian).

[5] Yu. N. Onopchuk, P. V. Beloshitsky, and N. I. Aralova, "To problem of reliability of functional organism systems," Cybernetics and computing technique, Kyiv, Glushkov Inst of Cubernetics, NASU, Is. 122, pp. 72-82, 1999. (in Russian).

[6] A. Z. Kolchinskaya, "Interval hypoxic training in sport of highest achievements," Sportive medicine, no. 1, pp. 9-25, 2008. (in Russian).

[7] A. Z. Kolchinskaya, "Mechanisms of interval hypoxic training action," Interval hypoxic training. Efficacy, mechanisms of action, Kyiv, 1992, pp. 107-113. (in Russian).

[8] Secondary tissue hypoxia. Edited by A. Z. Kolchinskaya. Kyiv, Naukova dumka, 1983. 253 p. (in Russian).
[9] Yu. N. Onopchuk. "Homeostasis of functional respiratory system as result of information interaction: internal system and system-media ones," Bioecomedicine. United information space. Kyiv, Naukova dumka, 2001, pp. 59-81 (in Russian).

[10] Yu. N. Onopchuk, "Imitation modeling of process of external respiration control and blood circulation in human organism," Cybernetics, Kyiv, no. 6, pp. 152154, 1979. (in Russian).

[11] Yu. N. Onopchuk, "About one model of blood flow distribution in human tissues and organism under the changed physical loading," Cybernetics and computing technique, Kyiv, Glushkov Inst of Cubernetics, NASU, Is. 48, pp. 55-59, 1980. (in Russian).

[12] L. S. Pontriagin, V. G. Boltiansky, and R. V. Gamkrelidze. Mathematic theory of optimal processes. Moskow: Fizmatgiz, 1961. 391 p. (in Russian).

[13] A. V. Bytz, D. I. Marchenko, and Yu. N. Onopchuk, "Means for prognosis of tissue blood flows in organism," Computer mathematic, no. 2, pp. 77-84, 2004. (in Russian).

[14] B. N. Pshenichnyy and Yu. M. Danilin, Numerical methods in extreme tasks. Moskow, Nauka, 1975. 320 p. (in Russian).

[15] Yu. N. Onopchuk, D. I. Marchenko, A. V. Bytz, and T. A. Semchik, "Prognosis of regional blood flows and mathematical methods for investigation of mechanisms for control of blood circulation system," Dopovidi NAS Ukraine, Kyiv, no. 7, pp. 71-76, 2002. (in Russian).

[16] N. I. Aralova, "Information technologies for decision making support during the rehabilitation of sportsmen of sportive single combats," Problems of control and informatics, no. 3, pp. 160-170, 2016. (in Russian).

[17] N. I. Aralova, O. M. Klyuchko, V. I. Mashkin, and I. V. Mashkina, "Mathematical model for research of organism restoring for operators of continuously interacted system," Electronics and control systems, Kyiv, vol. 49, no. 3, pp. 100-105, 2016.

Received January 19, 2017

Aralova Nataliya. Candidate of Science (Engineering). Senior researcher.

Institute of Cybernetics of V. M. Glushkov National Academy of Sciences of Ukraine, Kyiv, Ukraine.

Education: National University named after Taras Shevchenko, Kyiv, Ukraine, (1978).

Research area: control in biological and medical systems.

Publications: 99.

E-mail: aralova@ukr.net

Klyuchko Olena. Candidate of Science (Biophysics). Associate Professor. Senior researcher.

Educational \& Research Institute of Air Navigation, National Aviation University, Kyiv, Ukraine.

Education: National University named after Taras Shevchenko, Kyiv (1981), National Aviation University, Kyiv, Ukraine, (2003).

Research area: biophysics, ecology, bioinformatics, brain sciences. 
Publications: 179.

E-mail: iesy@nau.edu.ua

Mashkin Valery. Candidate of Science (Engineering). Senior researcher.

Institute of Cybernetics of V. M. Glushkov National Academy of Sciences of Ukraine, Kyiv, Ukraine.

Education: Kyiv Polytechnic Institute, Kyiv, Ukraine, (1967).

Direction of scientific activity: management of complex technical systems.

Publications: 70 .

E-mail: mashkin_v@ukr.net

Mashkina Irina. Candidate of Science (Engineering). Associate Professor.

Borys Grinchenko Kyiv University, Kyiv, Ukraine

Education: Maxim Gorky Kyiv Pedagogical Institute, Kyiv, Ukraine, (1984).

Direction of scientific activity: modeling of processes and systems.

Publications: 65 .

E-mail: mashkina.iv@gmail.com

Н. І. Аралова, О. М. Ключко, В. Й. Машкін, І. В. Машкіна. Алгоритмічне та програмне забезпечення для оптимізації вибору режимів інтервального гіпоксичного тренування льотчиків

Представлено комплекс математичного, алгоритмічного та програмного забезпечення для оптимізації вибору режимів інтервального гіпоксичного тренування для осіб льотного складу, спрямованого на підвищення адаптації, працездатності та резистентності членів льотних екіпажів. В основу покладено математичну модель масопереносу та масообміну кисню, вуглекислого газу та азоту в організмі людини. Розглядається задача прогнозування тканинних кровообігів, як розв'язок конфліктної ситуації, яка виникає в організмі людини при внутрішніх та зовнішніх збуреннях між тканинами керуючих органів та тканинами виконавчих органів саморегуляції. Розподіл системного кровообігу по тканинам здійснюється у відповідності до гіпоксичного або гіперкапнічного стимулу, тому поставлена задача формулюється як задача квадратичного програмування. Наведено ітераційну процедуру для вивчення та оцінки газового стану системи дихання при використанні інтервального гіпоксичного тренування, яке може сприяти підвищенню професійної майстерності льотних екіпажів, їх фізичної та психологічної працездатності та готовності до виконання складних учбових та бойових завдань в обмеженому просторі та умовах несприятливого зовнішнього середовища.

Ключові слова: інтервальне гіпоксичне тренування; математична модель системи дихання; вторинна тканинна гіпоксія; саморегуляція системи дихання.

Аралова Наталія Ігоревна. Кандидат технічних наук. Старший науковий співробітник.

Інститут кібернетики ім. В. М. Глушкова НАН України, Київ, Україна.

Освіта: Національний університет ім. Тараса Шевченка, Київ, Україна, (1978).

Напрям наукової діяльності: керування в біологічних і медичних системах.

Публікації: 99.

E-mail: aralova@ukr.net

Ключко Олена Михайлівна. Кандидат біологічних наук (біофізика). Доцент. Старший науковий співробітник. Навчально-науковий Інститут аеронавігації, Національний авіаційний університет, Київ, Україна.

Освіта: Національний університет ім. Тараса Шевченка, Київ, Україна, (1981); Національний Авіаційний університет, Київ, Україна, (2003).

Напрям наукової діяльності: біофізика, екологія, біоінформатика, науки про мозок.

Публікації: 179.

E-mail: iesy@nau.edu.ua

Машкін Валерій Йосипович. Кандидат технічних наук. Старший науковий співробітник.

Інститут кібернетики ім. В. М. Глушкова НАН України, Київ, Україна.

Освіта: Київський політехнічний інститут, Київ, Україна, (1967).

Напрямок наукової діяльності: управління в складних технічних системах.

Публікації: 70.

E-mail: mashkin_v@ukr.net

Машкіна Ірина Вікторівна. Кандидат технічних наук. Доцент.

Київський університет ім. Бориса Грінченка, Київ, Україна.

Освіта: Київський національний педагогічний інститут ім. М. Горького, Київ, Україна, (1984). 
Напрямок наукової діяльності: моделювання процесів та систем.

Публикації: 65.

E-mail: mashkina.iv@gmail.com

Н. И. Аралова, Е. М. Ключко, В. И. Машкин, И. В. Машкина. Алгоритмическое и программное обеспечение для оптимизации выбора режимов интервальной гипоксической тренировки летчиков

Представлен комплекс математического, алгоритмического и программного обеспечения для оптимизации выбора режимов интервальной гипоксической тренировки для лиц летного состава, направленный на повышение адаптации, работоспособности и резистентности членов летных экипажей. В основу положена математическая модель массопереноса и массообмена кислорода, углекислого газа и азота в организме человека. Рассматривается задача прогнозирования тканевого кровообращения, как решение конфликтной ситуации, которая возникает в организме человека при внутренних и внешних возмущениях между тканями управляющих органов и тканями исполнительных органов саморегуляции. Распределение системного кровообращения по тканям осуществляется в соответствии с гипоксическим или гиперкапническим стимулами, поэтому поставленная задача формулируется, как задача квадратичного программирования. Приведена итерационная процедура для изучения и оценки газового состояния системы дыхания при использовании интервальной гипоксической тренировки, которая может способствовать повышению профессионального мастерства летных экипажей, их физической и психологической работоспособности и готовности к выполнению сложных учебных и боевых задач в ограниченном пространстве и условиях неблагоприятной внешней среды.

Ключевые слова: интервальная гипоксическая тренировка; математическая модель системы дыхания; вторичная тканевая гипоксия; саморегуляция системы дыхания.

Аралова Наталья Игоревна. Кандидат технических наук. Старший научный сотрудник.

Институт кибернетики им. В. М. Глушкова НАН Украины, Киев, Украина.

Образование: Национальный университет им. Тараса Шевченко, Киев, Украина, (1978).

Направление научной деятельности: управление в биологических и медицинских системах.

Публикации: 99.

E-mail: aralova@ukr.net

Ключко Елена Михайловна. Кандидат биологических наук (биофизика). Доцент. Старший научный сотрудник. Учебно-научный Институт аэронавигации, Национальный авиационный университет, Киев, Украина.

Образование: Национальный университет им. Тараса Шевченко, Киев, Украина, (1981); Национальный авиационный университет, Киев, Украина, (2003).

Направление научной деятельности: биофизика, экология, биоинформатика, науки о мозге.

Публикации: 179.

E-mail: iesy@nau.edu.ua

Машкин Валерий Иосифович. Кандидат технических наук. Старший научный сотрудник

Институт кибернетики им. В. М. Глушкова НАН Украины, Киев, Украина.

Образование: Киевский политехнический институт, Киев, Украина, (1967).

Направление научной деятельности: управление в сложных технических системах.

Публикации: 70.

E-mail: mashkin_v@ukr.net

Машкина Ирина Викторовна. Кандидат технических наук. Доцент.

Киевский университет им. Бориса Гринченко, Киев, Украина.

Образование: Киевский национальный педагогический институт им. М. Горького, Киев, Украина, (1984).

Направление научной деятельности: моделирование процессов и систем.

Публикации: 65.

E-mail: mashkina.iv@gmail.com 